ozone transferring function when the fruit, \&c., containing it is cooked. It is not chlorophyll, as is shown by its situation, and it seems to be intimately associated with the vascular tissue. From analogy with the animal substances hremoglobin, fibrin, myosin, \&c., which have a similar action, it may be presumed to be proteinaceous, though I am unable to indicate its chemical and other characters more exactly. The interesting analogy between the respiratory functions of animals and plants indicated by these observations will, I hope, be considered a sufficient excuse if $I$ ask you to insert this short summary of my paper which you will receive at the same time. JAMES JAMIESON Melbourne, July 6

\section{The Electro-Magnet a Receiving Telephone}

The experiment of Mr. F. G. Lloyd, described in NATURE, vol. xviii. p. 488 , is simply a repetition of Page's original experiment, the basis of all telephony. The electro-magnets of ordinary relays and Morse apparatus make capital telephone receivers when their armatures are screwed up, and it is a common thing for operators at intermediate stations in America to enjoy the music that is being transmitted between the terminal stations during some telephonic display. I remember the station-master at Menlo Park telling me that the music sent from New York and received at Philadelphia was heard, much to his surprise and delight, all over his little wayside station. The effect is dependent upon the strength of the currents flowing. With a Riess' transmitter sending musical notes and voltaic currents it can be made very loud. With an Edison or a Hughes trans. mitter the effect is much less, and with a Bell transmitter it is almost, if not quite, inaudible.

Electro-magnets also can be used as transmitters, because their iron cores invariably contain some residual magnetism.

September 16

W. H. PreECE

\section{Rayons de Crépuscule}

IN your isste of July 25, Mr. Abbay, in writing of Ceylon, says that, as far as he is aware, the rayons de crépuscule are never seen in the low country.

Allow me to add the weight of my testimony to that of $\mathrm{Mr}$. Pringle, given in NATURe of August I.

During a residence of about five weeks here, the rays have been noticed from twelve to fifteen times, and I have been told by an old resident that their appearance is very common.

This country is the perfectly flat alluvial land, and marsh bordering the Gulf of Mexico, whose shores are distant about eight miles from our camp.

On fully half of the occasions have the bands been traced from the sun, without break, to the point in the east, $180^{\circ}$ from it. The rays are seen best when the sun is very near or below the horizon. On the evening of August x6, the display was exceptionally beautiful. The sun had set behind a bank of dense cumulus clouds, while the remainder of the heavens was covered with very faint cirro-cumulus clouds. A band of dark blue spread from the sun, and after widening to about $85^{\circ}$ near the zenith, converged to a point either in, or slightly below the horizon. This was the cloud's shadow. In the south a line about $15^{\circ}$ wide, and in the north, one about $80^{\circ}$ wide, were lighted up, and shone with brilliant tints, varying from rose to orange. The lines between the deep blue of the shadow, and the lighter blue, mottled with the shining, closely packed cloud flecks, were sharply marked, as sharply, indeed, as the arch in the Aurora, which it called to mind. I have noticed the phenomerion several times in Maryland, in a gently rolling country, but nowhere have I seen it as often and as distinctly as here.

JULIUS KRUTTSCHNITT

Morgan's La. and Texas R. R. Camp, St. Mary Parish, Louisiana, August 24

"LES rayons de crépuscule" seem not to be of uncommon occurrence. They presented a most superb spectacle at this place last Sunday evening. The weather had been extremely warm all day and the mountains were seen through a thick haze. At sunset masses of dark clouds, fringed with gold, lay along the horizon to the west, while beyond them the sky was of a beautiful pink. As the sun sank lower many bands of pink appeared, stretching from the west entirely across to the east, appearing broader and paler, of course, near the zenith.
They changed gradually in width, position, and number for perhaps half-an-hour, and then disappeared. Their changeableness indicated that they were due to clouds near the horizon.

Sing Sing-on-the-Hudson, September 3 H. S. Carhart

\section{The Microphone}

THE form of microphone described by $\mathrm{Mr}$. Gerald B. Francis (NATURE, vol, xviii. p. $3^{8} 3$ ) is easily made and very efficient. It not only did for me all its inventor promised, but with a common tumbler inverted over it upon the sounding-board so as to prevent direct impact of sound waves upon the ball; it became a powerful transmitter of the human voice. I conversed easily and satisfactorily with a friend a half-mile from my end of the wire. The exact contact of the lower wire with the ball was effected by a screw with a very fine thread passing through without touching the lower block or cup. The voice must be kept low to prevent bounding of the ball so as to break contact. Bell telephones were used as receiving instruments, the batteries being Hill and Calland gravity batteries used extensively in this country upon telegraph lines. These batteries agree exactly in every respect with the one used by Prof. Hughes in his interesting experiments excepting the clay, which is not necessary, and must be a great inconvenience in a permanent arrangement.

Port Jervis, New York, August 30

S. T. BARRETT

\section{A White Swallow.-Albinism in Birds}

BY the side of a steep sand-cliff overhanging a stream-the Cambeck, in Cumberland-I lately saw, on a glorious summer afternoon, a white swallow flying about with many other birds of the same species. A most beautiful bird it was; perfectly snow white, with perhaps a slight tinge of blueish grey near the roots of the tail-feathers. In size it seemed to be rather smaller than the swallows around it; but in its flight and pursuit of insects there was no noticeable difference. From my position at the top of the cliff I could often see the bird within a very few yards of me.

Like the grouse of which Sir Joseph Fayrer writes in NATURE (vol. xviii. p. $5 \mathrm{I} 8$ ), this white swallow is, I believe, of considerable rarity. I have been able to hear of only one, seen many years ago near Repton, in Derbyshire ; and in numerous works on British and other birds which I have consulted, I cannot find any very precise mention of a white variety. Magillivray remarks of the Hirundo riparia, the species to which the bird I saw belonged, that "individuals of a whitish colour are said to" occur, but I have never met with any remarkable deviations from the ordinary appearance." Yarrel speaks of a white variety of the common swallow as not uncommon; while of the same swallow, or Hirundo dontestica, several varieties are recorded by Buffon, and among them the white, there being "no country in Europe where these have not been seen, from the Archipelago to Prussia."

Able to catch flies on a cloudless summer day, this white swallow can, I hardly think, have been an albino, although I had no opportunity of such close inspection as Sir Joseph Fayrer had of the grouse he shot near Dunrobin. Albinism in birds must, I should imagine, be altogether unknown or unobserved, for I can nowhere meet with any account of it. Undoubted albinos are sometimes spoken of as "white varieties"-an albino monkey is, or lately was, so labelled at the Zoological Gardens; and it is possible that this very general term may include some cases of albinism, even among birds.

New Cavendish Street, W., September 16

$$
\text { Herbert W. Page }
$$

\section{The Hearing of Insects}

I AM not aware if it is generally known that there is a wasp in South America which seems to present undoubted evidence of a faculty to hear, or it may be to feel, and distinguish certain vibrations of sound.

The wasp is a common one on the Guayaquil River; a large slender black species, much feared on account of the virulence of his sting, which not unfrequently produces fever. I, myself, though little susceptible to the bites of mosquitoes or flies, and the stings of scorpions, \&c., when once stung on the finger by 